\title{
Serum Uric Acid to Creatinine Ratio as a Predictor of Metabolic Syndrome in Healthy Adults Men
}

\author{
Myong Soo Kim ${ }^{1}$, Kyung A Shin ${ }^{2}$ \\ ${ }^{1}$ Department of Laboratory Medicine, Samsung Medical Center, Seoul, Korea \\ ${ }^{2}$ Department of Clinical Laboratory Science, Shinsung University, Dangjin, Korea
}

\section{건강한 성인 남성의 대사증후군 위험 예측인자로서 혈청 요산/ 크레아티닌 비율}

\author{
김명수 ${ }^{1}$, 신경아 $^{2}$ \\ ${ }^{1}$ 삼성서울병원 진단검사의학과, ${ }^{2}$ 신성대학교 임상병리과
}

\begin{abstract}
This study compared the utility of the serum uric acid/creatinine ratio with that of uric acid as a risk predictor of metabolic syndrome. From November 2016 to October 2018, 14,190 adult men under the age of 20 years, who underwent a comprehensive health checkup at a general hospital in their metropolitan area, were included. Metabolic syndrome was assessed according to the American Heart Association/National Heart Lung and Blood Institute (AHA/NHLBI) criteria. Abdominal obesity was based on the WHO criteria in the Western Pacific region. The serum uric acid/creatinine ratio was found to be higher in the fourth quartile than in the first quartile, with a high incidence of metabolic syndrome and metabolic syndrome components. On the other hand, ROC analysis revealed the serum uric acid/creatinine ratio to be a similar indicator of the metabolic syndrome risk to serum uric acid (AUC, 0.554 vs 0.566). The serum uric acid/creatinine ratio showed lower sensitivity and higher specificity than uric acid. In conclusion, the utility of the serum uric acid/creatinine ratio as an independent indicator to predict the risk of metabolic syndrome is limited, and should be used only as an auxiliary marker.
\end{abstract}

Key words: Creatinine, Metabolic syndrome, Risk factor, Serum uric acid

This is an Open Access article distributed under the terms of the Creative Commons Attribution Non-Commercial License (http://creativecommons.org/licenses/by-nc/4.0) which permits unrestricted non-commercial use, distribution, and reproduction in any medium, provided the original work is properly cited.

Copyright @ 2019 The Korean Society for Clinical Laboratory Science. All rights reserved.
Corresponding author: Kyung A Shin Department of Clinical Laboratory Science, Shinsung University, 1 Daehak-ro, Jeongmi-myeon, Dangjin 31801, Korea Tel: $82-41-350-1408$ Fax: 82-41-350-1355

E-mail: mobitz2@hanmail.net ORCID: https://orcid.org/0000-0001-5266-5627

Received: January 2, 2019

Revised $1^{\text {st: }}$ January 29, 2019

Revised 2 ${ }^{\text {nd }}$ : February 12, 2019

Accepted: February 13, 2019

\section{서 론}

대사증후군(metabolic syndrome, MetS)은 심혈관 질환 및 뇌졸중 위험도 증가, 심뇌혈관 질환과 관련된 다양한 대사 이상 을 의미하며, 대사증후군 구성요소에는 복부비만, 고중성지방 혈증 및 저 고밀도 지단백 콜레스테롤(high density lipoprotein, $\mathrm{HDL}-\mathrm{C}$ )혈증을 포함한 이상지질혈증, 혈압상승, 공복 혈당장애 가 포함된다[1]. National Cholesterol Education Program
(NCEP)의 Adult Treatment Panel (ATP) III, 국제당뇨병연맹 (International Diabetes Federation, IDF) 및 세계보건기구 (World Health Organization, WHO)에서 제안한 대사증후군 의 정의에 다소 차이가 있으나, 인슐린 저항성과 복부비만은 대 사증후군 발병 진행의 중요한 요소로 제시된다[2-4]. 대사증후 군은 심혈관 질환, 제2형 당뇨병, 만성 콩팥질환의 발병 위험이 높은 환자를 확인하는데 도움이 되며, 자율신경계 및 염증반응, 폐기능과 관련된다고 보고되고 있어 임상적으로 중요성이 강조 
된다[5-9].

특히 최근 대사증후군과 만성 콩팥질환간의 관련성에 대한 관심이 증가하고 있다. 당뇨병과 고혈압은 만성 콩팥질환의 주 요 원인이며, 공복 혈당장애와 혈압상승은 대사증후군 정의에 포함되기 때문에 대사증후군과 만성 콩팥질환 진행 사이에 독 립적인 연관성이 보고된다[10]. 만성 콩팥질환의 초기 단계는 전형적인 증상이 없어 진단이 어렵기 때문에 대사증후군의 진 행을 예방하는 것이 만성 콩팥질환 및 심혈관 질환의 병인 발생 과 진행을 예방하는 방법일 수 있다[11].

혈청 크레아티닌은 사구체 여과율(glomerular filtration rate, GFR)의 변화를 발견하기 위해 일반적으로 사용되며, 초기 만성 콩팥질환을 진단하는 생리적 지표이다[12]. 또한 크레아 티닌 증가는 심혈관 질환, 비만 및 고혈압, 대사증후군 위험 증 가와 관련이 있다고 보고된다[13, 14]. 유사하게, 혈청 요산 증 가는 콩팥기능의 감소를 나타내는 지표로서 고혈압 및 심혈관 질환, 대사증후군의 위험인자로 알려져 있다[15, 16]. 혈청 요 산은 퓨린 대사의 최종 생성물이며, 주로 간에서 합성되어 콩팥 을 통해 소변으로 배설된다[17]. 혈중 요산은 대사증후군과 관 련이 있는 것으로 보고되고 있다[16]. 대사증후군에서 인슐린 저항성은 콩팥의 요산 재흡수를 증가시켜 혈중 요산치 상승에 기여하고 고요산혈증은 산화질소의 활성을 저해하여 인슐린 저 항성을 가속화시킨다[16, 18]. 콩팥을 통한 혈청 요산의 제거가 콩팥기능에 영향을 받는다는 것을 고려하여 콩팥기능 을 반영한 혈청 요산/크레아티닌 비율이 생성되었다[19]. Gu 등[19]은 혈 청 요산/크레아티닌 비율이 요산 단독 측정보다 만성 콩팥질환 과 밀접한 관련이 있음을 입증하였다. 또한 Al-Daghri 등[11]은 제2형 당뇨환자를 대상으로 대사증후군 위험요인이 증가할수 록 혈청 요산/크레아티닌 비율이 증가하며, 혈청 요산/크레아 티닌 비율은 대사증후군의 예후를 결정하는데 유용하다고 보고 하였다.

그러나 이와 같은 연구들은 특정 질환자를 대상으로 하였으 며[11, 19], 특히 국내에서는 혈청 요산/크레아티닌 비율과 대 사증후군과의 연관성을 확인한 연구는 제한적이다[20]. 한국인 을 대상으로 한 연구는 국민건강영양 조사자료를 이용하여 대 사증후군 구성요소와 혈청 요산/크레아티닌 비율간의 상관성 을 확인한 연구가 유일하며[20], 혈청 요산/크레아티닌 비율의 임상적 유용성에 대해서는 알려지지 않았다. 또한 대사증후군 은 진단기준, 인종, 성별, 연령에 따라 다양한 결과를 보이고 있 어, 국내에서 대사증후군 예측지표로서 혈청 요산/크레아티닌 비율을 평가하는 것은 의미가 있다 하겠다.

이에 본 연구에서는 건강한 성인 남성을 대상으로 수신자 조
작 특성(receiver operating characteristic, ROC)곡선 분석을 통해 대사증후군 위험 예측인자로서 요산과 비교하여 혈청 요 산/크레아티닌 비율의 유용성을 확인해보고자 하였다.

\section{재료 및 방법}

\section{1. 연구 대상}

본 연구는 2016년 11월부터 2018년 10월까지 수도권 소재 의 일개 종합병원에서 종합건강검진을 받은 20 세 이상 80 세 미 만의 성인 남성을 대상으로 수행되었다. 자기 기입식 건강설문 조사를 통해 갑상선 질환자, Anti-HCV Ab 또는 $\mathrm{HBs} \mathrm{Ag}$ 양성자 를 포함한 간 질환자, 통풍 질환자, 콩팥 질환자, 뇌졸중 및 심근 경색, 협심증 환자와 모든 측정지표에 결측치를 포함한 대상자 를 제외한 최종 연구 대상자는 14,190 명이었다. 본 연구는 수도 권 소재 종합병원 생명윤리심의위원회의 승인을 받아 진행하였 다(IRB No: D-2018-012-2468).

\section{2. 연구방법}

\section{1) 대사증후군 진단기준}

대사증후군 진단기준은 NCEP-ATP III 기준을 변형한 American Heart Association/National Heart Lung and Blood Institute (AHA/NHLBI)의 기준에 따라 5가지 대사증후군 구성 요소 중 3가지 이상 해당되는 경우 대사증후군으로 평가하였다. 5 가지 대사증후군 구성요소는 공복혈당 $\geq 100 \mathrm{mg} / \mathrm{dL}$, 중성지 방 $\geq 150 \mathrm{mg} / \mathrm{dL}$, 저밀도 콜레스테롤은 남성 $<40 \mathrm{mg} / \mathrm{dL}$, 수축 기 혈압 $\geq 130 \mathrm{mmHg}$ 또는 이완기 혈압 $\geq 85 \mathrm{mmHg}$, 복부비만 은 $\mathrm{WHO}$ 서태평양지역의 기준인 허리둘레는 남성 $>90 \mathrm{~cm}$ 을 적용하였다[21, 22].

\section{2) 신체계측 및 혈액검사}

신장과 체중은 직립자세에서 체성분 분석기 Inbody 720 (Biospace Co., Seoul, Korea)을 활용하여 생체 임피던스법으 로 측정하였고, 체질량지수(body mass index, BMI)는 체중 $(\mathrm{kg})$ 을 키 $\left(\mathrm{m}^{2}\right)$ 로 나누어 계산하였다. 허리둘레는 양발을 25 $30 \mathrm{~cm}$ 으로 벌려 체중을 분산시킨 후 숨을 내쉰 상태로 늑골 하 부(lower border of rib cage)와장골능 상부(top of iliac crest) 의 중간 부분을 줄자로 $0.1 \mathrm{~cm}$ 까지 측정하였다. 수축기 혈압과 이완기 혈압은 5 분 동안 안정상태를 유지한 후 아네로이드 혈압 계(Medisave UK Ltd., Weymouth, UK)로 측정하였다. 혈액분 석은 8시간 이상 공복상태에서 오전에 채혈하여 측정하였으며, 혈청 총 콜레스테롤(total cholesterol, TC), 중성지방(trigly- 
ceride, TG), HDL-C, 저밀도 지단백 콜레스테롤(low density lipoprotein, LDL-C), 공복혈당, 요산, 혈액 요소질소(blood urea nitrogen, BUN), 크레아티닌은 TBA-2000FR NEO 자동 생화학분석기(Toshiba, Tokyo, Japan)로 분석하였다. 또한 당 화혈색소(hemoglobin A1c, HbA1c)는 Variant II (Bio Rad, CA, USA)로, 인슐린은 Roche Modular Analytics E170 (Roche, Mannheim, Germany)으로 측정하였다.

\section{3. 통계분석}

이 연구의 통계처리는 SPSS version 24.0 (SPSS Inc., Chicago, IL, USA)으로 실시하였다. 요산/크레아티닌 비율의 사분위수에 따른 연구 대상자의 일반적 특징의 차이 및 대사증 후군 구성요소의 개수에 따른 요산/크레아티닌 비율의 차이는 일원변량분석(one-way ANOVA)을 통해 확인하였으며, 사후 검증은 Scheffe법으로 검증하였다. 또한 요산/크레아티닌 비율 의 사분위수에 따른 대사증후군 및 대사증후군 구성요소의 발 병률의 차이를 비교하고자 카이제곱 검정(chi-squared test)을 시행하였다. 요산 및 요산/크레아티닌 비율 수준에 따른 대사증 후군 발병률의 차이는 연령과 BMI를 통제한 상태에서 로지스틱 회귀분석(logistic regression)을 통해 위험비(odds ratio)와 95\% 신뢰구간(95\% confidence interval)을 구하였다. 요산/크 레아티닌 비율은 정규성 가정에 위배되어 로그변환을 하였다. 또한 요산/크레아티닌 비율의 대사증후군 예측력을 확인하기 위해 요산과 비교하여 요산/크레아티닌 비율의 ROC 곡선을 이 용한 곡선하 면적(area under curve, AUC) 값을 구하였다. 대 사증후군을 예측하기 위한 요산/크레아티닌 비율과 요산의 최

Table 1. General characteristic of subjects based on uric acid/creatinine ratio quartile

\begin{tabular}{|c|c|c|c|c|c|}
\hline Variables & $\begin{array}{c}1^{\text {st }} \text { quartile } \\
(<4.48)\end{array}$ & $\begin{array}{c}2^{\text {nd }} \text { quartile } \\
(4.49 \sim 5.15)\end{array}$ & $\begin{array}{c}3^{\text {rd }} \text { quartile } \\
(5.16 \sim 5.88)\end{array}$ & $\begin{array}{c}4^{\text {th }} \text { quartile } \\
(5.89 \leq)\end{array}$ & $P$-value \\
\hline N & 2,479 & 3,208 & 3,924 & 4,579 & \\
\hline $\mathrm{UA} / \mathrm{Cr}$ ratio & $3.66 \pm 0.49$ & $4.59 \pm 0.19^{\mathrm{a}}$ & $5.26 \pm 0.21^{\mathrm{ab}}$ & $6.43 \pm 0.70^{\mathrm{abc}}$ & $<0.001$ \\
\hline \multicolumn{6}{|l|}{ Clinical characteristics } \\
\hline Age (years) & $49.18 \pm 11.84$ & $46.61 \pm 10.77^{\mathrm{a}}$ & $44.74 \pm 10.30^{\mathrm{ab}}$ & $43.60 \pm 10.27^{\mathrm{abc}}$ & $<0.001$ \\
\hline Height $(\mathrm{cm})$ & $170.57 \pm 6.49$ & $171.29 \pm 6.22^{\mathrm{a}}$ & $171.72 \pm 6.23^{\mathrm{ab}}$ & $171.86 \pm 6.43^{\mathrm{ab}}$ & $<0.001$ \\
\hline Weight (kg) & $70.14 \pm 9.97$ & $71.18 \pm 9.33^{\mathrm{a}}$ & $72.74 \pm 9.96^{\mathrm{ab}}$ & $74.75 \pm 10.86^{\mathrm{abc}}$ & $<0.001$ \\
\hline $\mathrm{BMI}\left(\mathrm{kg} / \mathrm{m}^{2}\right)$ & $24.07 \pm 2.96$ & $24.25 \pm 2.78$ & $24.63 \pm 2.86^{\mathrm{ab}}$ & $25.26 \pm 3.08^{\mathrm{abc}}$ & $<0.001$ \\
\hline$W C(\mathrm{~cm})$ & $82.36 \pm 7.76$ & $82.64 \pm 7.36$ & $83.65 \pm 7.41^{\mathrm{ab}}$ & $85.28 \pm 7.59^{\mathrm{abc}}$ & $<0.001$ \\
\hline $\mathrm{SBP}(\mathrm{mmHg})$ & $112.49 \pm 13.93$ & $111.96 \pm 12.82$ & $112.45 \pm 12.76$ & $113.43 \pm 12.78^{\mathrm{abc}}$ & $<0.001$ \\
\hline DBP (mmHg) & $72.45 \pm 9.85$ & $72.45 \pm 9.72$ & $72.89 \pm 9.83$ & $73.59 \pm 10.00^{\mathrm{abc}}$ & $<0.001$ \\
\hline \multicolumn{6}{|l|}{ Lipid profile } \\
\hline $\mathrm{TC}(\mathrm{mg} / \mathrm{dL})$ & $189.55 \pm 33.69$ & $193.94 \pm 33.43^{\mathrm{a}}$ & $195.45 \pm 33.17^{\mathrm{a}}$ & $199.26 \pm 34.95^{\mathrm{abc}}$ & $<0.001$ \\
\hline $\mathrm{TG}(\mathrm{mg} / \mathrm{dL})$ & $127.02 \pm 75.11$ & $134.11 \pm 87.89^{a}$ & $139.77 \pm 83.89^{\mathrm{a}}$ & $166.25 \pm 113.39^{\mathrm{abc}}$ & $<0.001$ \\
\hline $\mathrm{HDL}-\mathrm{C}(\mathrm{mg} / \mathrm{dL})$ & $53.66 \pm 12.72$ & $52.50 \pm 12.01^{\mathrm{a}}$ & $51.94 \pm 11.85^{\mathrm{a}}$ & $50.85 \pm 11.75^{\mathrm{abc}}$ & $<0.001$ \\
\hline LDL-C (mg/dL) & $116.81 \pm 30.44$ & $121.27 \pm 29.45^{\mathrm{a}}$ & $123.02 \pm 29.90^{\mathrm{a}}$ & $124.97 \pm 31.72^{\mathrm{abc}}$ & $<0.001$ \\
\hline \multicolumn{6}{|l|}{ Glycemic profile } \\
\hline Glucose (mg/dL) & $97.40 \pm 29.20$ & $92.70 \pm 21.01^{\mathrm{a}}$ & $90.58 \pm 16.26^{\mathrm{ab}}$ & $90.92 \pm 15.86^{\mathrm{ab}}$ & $<0.001$ \\
\hline $\mathrm{HbA} 1 \mathrm{c}(\%)$ & $5.88 \pm 1.15$ & $5.66 \pm 0.78^{\mathrm{a}}$ & $5.58 \pm 0.62^{\mathrm{ab}}$ & $5.56 \pm 0.54^{\mathrm{ab}}$ & $<0.001$ \\
\hline Insulin $(\mu \mathrm{U} / \mathrm{mL})$ & $4.94 \pm 3.16$ & $4.97 \pm 3.24$ & $5.09 \pm 3.03$ & $5.62 \pm 3.45^{\mathrm{abc}}$ & $<0.001$ \\
\hline \multicolumn{6}{|l|}{ Renal profile } \\
\hline BUN (mg/dL) & $14.67 \pm 4.34$ & $14.34 \pm 3.54^{\mathrm{a}}$ & $14.12 \pm 3.38^{\mathrm{a}}$ & $13.92 \pm 3.31^{\mathrm{ab}}$ & $<0.001$ \\
\hline Creatinine (mg/dL) & $1.21 \pm 0.22$ & $1.19 \pm 0.12^{\mathrm{a}}$ & $1.17 \pm 0.11^{\mathrm{ab}}$ & $1.13 \pm 0.11^{\mathrm{abc}}$ & $<0.001$ \\
\hline Uric acid (mg/dL) & $4.40 \pm 0.80$ & $5.45 \pm 0.58^{\mathrm{a}}$ & $6.14 \pm 0.62^{\mathrm{ab}}$ & $7.28 \pm 0.97^{\mathrm{abc}}$ & $<0.001$ \\
\hline \multicolumn{6}{|l|}{ MetS components (\%) } \\
\hline MetS & $273(11.0)$ & $297(9.3)$ & $408(10.4)$ & $663(14.5)$ & $<0.001$ \\
\hline Elevated WC & $410(16.5)$ & $541(16.9)$ & $802(20.4)$ & $1,212(26.5)$ & $<0.001$ \\
\hline Elevated BP & $447(18.0)$ & $484(15.1)$ & $643(16.4)$ & $841(18.4)$ & 0.001 \\
\hline Reduced HDL-C & $273(11.0)$ & $401(12.5)$ & $482(12.3)$ & $714(15.6)$ & $<0.001$ \\
\hline Elevated fasting glucose & 589 (23.8) & $580(18.1)$ & $608(15.5)$ & $752(16.4)$ & $<0.001$ \\
\hline Elevated TG & $701(28.3)$ & $976(30.4)$ & $1,349(34.4)$ & $2,026(44.2)$ & $<0.001$ \\
\hline
\end{tabular}

Values are presented as means \pm standard deviations and number (\%).

a, significantly different from the 1st quartile; b, significantly different from 2nd quartile; c, significantly different from 3rd quartile. Abbreviations: UA/Cr, uric acid/creatinine; BMI, body mass index; WC, waist circumference; SBP, systolic blood pressure; DBP, diastolic blood pressure; TC, total cholesterol; TG, triglyceride; HDL-C, high density lipoprotein cholesterol; LDL-C, low density lipoprotein cholesterol; HbA1c, hemoglobin A1c; BUN, blood urea nitrogen; MetS, metabolic syndrome. 
적 절단값(optimum cut-off values)은 민감도(sensitivity)와 특이도(specificity)의 합이 최대가 되는 지점의 값을 적정 절단 값으로 선택하였다. 이 연구에서 모든 통계분석의 유의수준은 $P<0.05$ 를 기준으로 설정하였다.

\section{결 과}

\section{1. 요산/크레아티닌 비율의 사분위수에 따른 연구 대상자의 일반적 특징}

요산/크레아티닌 비율의 사분위수에 따른 대상자의 일반적 특징은 Table 1과 같다. 연령, 신장, 체중은 사분위수가 증가할 수록 비례하여 증가하였다(각각 $P<0.001)$. BMI와 허리둘레, 수축기와 이완기 혈압은 4 사분위수에서 가장 높은 수치를 보였 다(각각 $P<0.001$ ). 혈액분석 항목 중 $\mathrm{TC}, \mathrm{TG}, \mathrm{LDL}-\mathrm{C}$ 은 1 사분 위수보다 상위 분위수에서 높게 나타났으며, 4 사분위수는 3 사 분위수보다도 높았다(각각 $P<0.001)$. 그러나 HDL-C은 1사분 위수보다 상위 분위수에서 낮게 나타났고, 4 사분위수는 3 사분 위수보다도 낮았다 $(P<0.001)$. 공복혈당과 $\mathrm{HbA1c}$ 은 1 사분위 수보다 상위 분위수에서 낮았으며, 3 사분위수와 4 사분위수는 2 사분위수보다 낮았다 $(P<0.001)$. 인슐린은 4 사분위수가 하위 분위수보다 높게 나타났다 $(P<0.001)$. BUN은 1 사분위수보다 상위 분위수에서 낮았으며, 4 사분위수는 2 사분위수보다 낮았 다 $(P<0.001)$. 크레아티닌은 1 사분위수보다 상위 분위수에서 낮았고 3 사분위수와 4 사분위수는 2 사분위수보다 낮았으며, 4 사분위수는 3 사분위수보다 낮았다 $(P<0.001)$. 요산은 1 사분위 수보다 상위 분위수에서 높았고 3 사분위수와 4 사분위수는 2 사

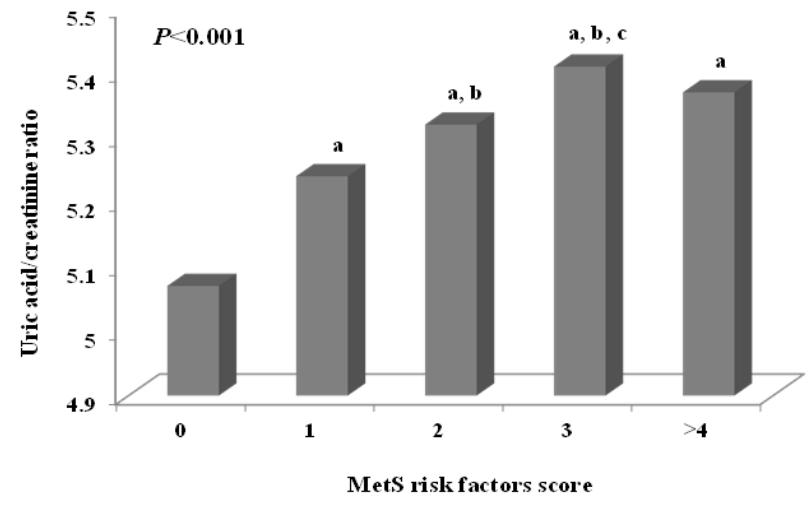

Figure 1. The values of uric acid/creatinine ratio according to number of metabolic syndrome components. a, significantly different from the MetS components $0 ; \mathrm{b}$, significantly different from MetS components 1; c, significantly different from MetS components 2. Data are mean \pm SD. MetS components 0: $5.07 \pm 1.02$, MetS components 1: $5.24 \pm 1.09$, MetS components $2: 5.32 \pm 1.15$, MetS components 3: $5.41 \pm 1.21$, MetS components $4: 5.37 \pm 1.27$. Abbreviation: MetS, metabolic syndrome.
분위수보다 높았으며, 4 사분위수는 3 사분위수보다 높았다(각 각 $P<0.001)$. 대사증후군 발생빈도는 4 사분위수에서 $14.5 \%$ 로 가장 높은 빈도를 보였으며, 허리둘레 증가는 사분위수가 증 가할수록 발생빈도가 증가하였다(각각 $P<0.001$ ). 높은 혈압 $(P=0.001)$ 과 $\mathrm{HDL}-\mathrm{C}(P<0.001)$ 의 감소는 4 사분위수에서 각 각 $18.4 \%$ 와 $15.6 \%$ 로 가장 높은 발생빈도를 보였다. 공복혈당 증가는 1 사분위수에서 $23.8 \%$ 로 가장 높은 발생빈도를 보였으 며, TG 증가는 사분위수가 증가할수록 발생빈도가 증가하였다 (각각 $P<0.001$ ).

\section{2. 대사증후군 구성요소의 개수에 따른 요산/크레아티닌 비율의 차이}

대사증후군 구성요소의 개수에 따른 요산/크레아티닌 비율의 차이를 확인한 결과 대사증후군 구성요소가 없는군보다 1 개, 2 개, 3 개, 4 개 이상의 구성요소를 가진군에서 요산/크레아티닌 비율이 높았으며, 대사증후군 구성요소를 2 개, 3 개 가진군은 1 개, 2 개의 구성요소를 가진군보다 높게 나타났다 $(P<0.001)$ (Figure 1).

\section{3. 요산/크레아티닌 비율 및 요산의 사분위수에 따른 대사증후군과의 관련성}

요산/크레아티닌 비율의 사분위수에 따른 대사증후군 발병 위험비는 보정을 하지 않은 경우 1 사분위수를 기준으로 2 사분 위수( $P=0.023)$ 에서 0.82 배(0.685 0.972) 낮았으며, 4 사분위 수 $(P<0.001)$ 에서는 1.37 배(1.175 1.586) 높았다. 그러나 연 령과 BMI를 통제한 후 요산/크레아티닌 비율은 대사증후군 발 병 위험과 관련이 없었다(Table 2). 요산의 사분위수에 따른 대 사증후군 발병 위험비는 보정을 하지 않은 경우 1 사분위수를 기 준으로 3사분위수 $(P=0.016)$ 에서 1.21배(1.035 1.411), 4사 분위수 $(P<0.001)$ 에서 1.65 배(1.425 1.903) 높게 나타났다. 그러나 연령과 $\mathrm{BMI}$ 를 통제한 후 요산은 1사분위수를 기준으로 4 사분위수 $(P=0.036)$ 에서 1.18배(1.011 1.407) 대사증후군 발병 위험이 높았다(Table 2).

\section{4. 대사증후군을 예측하기 위한 요산/크레아티닌 비율 및 요산의 절단값}

대사증후군 예측을 위한 요산/크레아티닌 비율의 곡선하면 적(area under the curve, AUC) 값은 0.554이며, 요산의 AUC 값은 0.566 이었다(Table 3, Figure 2). 대사증후군 예측을 위한 요산/크레아티닌 비율의 절단값은 5.75, 민감도는 $37.4 \%$, 특이 도는 $72.0 \%$ 로 나타났다 $(P<0.001)$. 요산의 대사증후군 예측을 위한 절단값은 $6.35 \mathrm{mg} / \mathrm{dL}$ 이며, 민감도는 $48.1 \%$, 특이도는 
46 Myong Soo Kim and Kyung A Shin. Serum Uric Acid to Creatinine Ratio as a Predictor of Metabolic Syndrome

Table 2. Odds ratio for the metabolic syndrome according to the uric acid/creatinine ratio quartile

\begin{tabular}{|c|c|c|c|c|}
\hline \multirow{2}{*}{$\mathrm{UA} / \mathrm{Cr}$ ratio } & \multicolumn{4}{|c|}{ Prevalence of MetS } \\
\hline & Crude $(95 \% \mathrm{Cl})$ & $P$-value & Adjusted $(95 \% \mathrm{Cl})$ & $P$-value \\
\hline $1^{\text {st }}$ quartile & 1 & & 1 & \\
\hline $2^{\text {nd }}$ quartile & $0.816(0.685 \sim 0.972)$ & 0.023 & $0.853(0.703 \sim 1.034)$ & 0.106 \\
\hline $3^{\text {rd }}$ quartile & $0.951(0.809 \sim 1.118)$ & 0.540 & $0.948(0.791 \sim 1.135)$ & 0.561 \\
\hline $4^{\text {th }}$ quartile & $1.365(1.175 \sim 1.586)$ & $<0.001$ & $1.171(0.986 \sim 1.390)$ & 0.071 \\
\hline \multirow{2}{*}{ Uric acid (mg/dL) } & \multicolumn{4}{|c|}{ Prevalence of MetS } \\
\hline & Crude $(95 \% \mathrm{Cl})$ & $P$-value & Adjusted $(95 \% \mathrm{Cl})$ & $P$-value \\
\hline $1^{\text {st }}$ quartile & 1 & & 1 & \\
\hline $2^{\text {nd }}$ quartile & $0.931(0.792 \sim 1.094)$ & 0.386 & $0.911(0.763 \sim 1.088)$ & 0.305 \\
\hline $3^{\text {rd }}$ quartile & $1.209(1.035 \sim 1.411)$ & 0.016 & $1.050(0.883 \sim 1.247)$ & 0.583 \\
\hline $4^{\text {th }}$ quartile & $1.647(1.425 \sim 1.903)$ & $<0.001$ & $1.183(1.011 \sim 1.407)$ & 0.036 \\
\hline
\end{tabular}

Adjusted odds ratios for age, BMI.

Abbreviations: MetS, metabolic syndrome; $\mathrm{UA} / \mathrm{Cr}$, uric acid/creatinine; $\mathrm{Cl}$, confidence interval.

Table 3. ROC analysis for uric acid/creatinine ratio and uric acid associated with metabolic syndrome

\begin{tabular}{cccccc}
\hline Variables & AUC $(95 \% \mathrm{Cl})$ & Cutoff value & Sensitivity $(\%)$ & Specificity $(\%)$ & $P$-value \\
\hline Uric acid/creatinine ratio & $0.554(0.539 \sim 0.570)$ & 5.75 & 37.4 & 72.0 & $<0.001$ \\
Uric acid $(\mathrm{mg} / \mathrm{dL})$ & $0.566(0.550 \sim 0.581)$ & 6.35 & 48.1 & 62.6 & $<0.001$ \\
\hline
\end{tabular}

Abbreviations: ROC, receiver operating characteristic; $\mathrm{Cl}$, confidence interval.

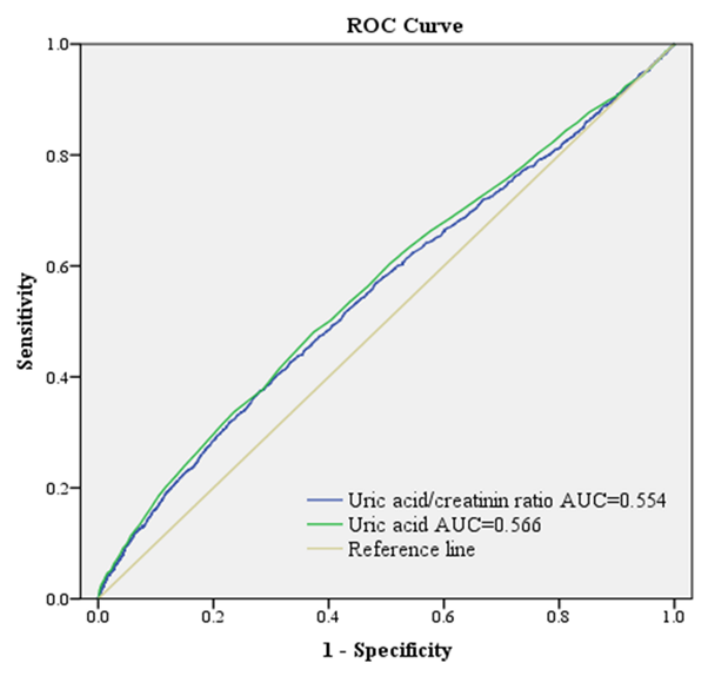

Figure 2. ROC curve of uric acid/creatinine ratio and uric acid for diagnosis of metabolic syndrome.

Abbreviations: ROC, receiver operating characteristic; AUC, area under the curve.

62.6\%였다 $(P<0.001)$ (Table 3).

\section{고 찰}

이 연구는 건강한 성인 남성에서 혈청 요산/크레아티닌 비율
이 대사증후군을 예측하는 지표로 활용될 수 있는지를 평가하 고자 하였다. 혈청 요산/크레아티닌 비율은 4 사분위수가 1 사분 위수보다 대사증후군 및 대사증후군 구성요소의 높은 발생빈도 를 보였다. 그러나 ROC 분석 결과 혈청 요산/크레아티닌 비율 은 대사증후군 위험 예측에 있어 혈청 요산치보다 더 유용한 지 표는 아니었으며(AUC, 0.554 vs 0.566), 요산치보다 낮은 민감 도와 높은 특이도를 보였다.

이전 연구에 따르면 고요산혈증은 높은 BMI, 이상지질혈증 및 고혈압과 관련이 있는 것으로 보고된다[23, 24]. 인슐린 저항 성은 이러한 대사장애의 발달과 함께 고요산혈증을 유발하는 기전으로 의심되지만, 그 기전은 아직 명확하지 않다[11]. 메타 분석에 의하면 혈청 요산치가 $1 \mathrm{mg} / \mathrm{dL}$ 증가할 때마다 제 2 형 당 뇨병의 위험이 $17 \%$ 증가한다고 보고되며[25], 최근에 혈중 요 산치가 당뇨환자와당뇨가 없는 환자 모두에서 콩팥손상을 예측 하는 지표로 제시된다[26, 27]. 임상시험을 통해서 혈청 요산치 를 낮추는 것이 콩팥질환의 진행을 지연시킬 수 있으며, 알로푸 리놀(allopurinol)로 통풍치료를 받은 환자가 위약군보다 더 안 정적인 콩팥기능을 나타낸다고 보고된다[28]. 일부 연구에서 결 과가 상충되고 있지만 혈청 요산치는 대부분의 연구에서 콩팥질 환을 예측하는 것으로 나타났다[29, 30]. 이것은 혈청 요산치와 사구체 여과율 사이의 강한 상호작용 때문으로 생각된다[31]. 
요산은 퓨린 대사의 최종산물로서 주로 소변으로 제거되며, 콩팥질환에서 요산 제거 장애로 혈청 요산치가 증가하는 것은 추론 가능하다[32]. 또한 크레아티닌 증가는 심혈관 질환 및 대 사증후군 위험 증가와 관련이 있다고 보고된다[13, 14]. 이전의 연구가 대개 혈청 요산치에 초점을 맞추었으나, 혈청 요산 및 크 레아티닌은 대사증후군을 예측하는데 사용될 수 있다는 제한된 증거로 인해 콩팥기능을 고려한 혈청 요산/크레아티닌 비율이 생성되었다[19].

혈청 요산/크레아티닌 비율은 제2형 당뇨환자에서 대사증후 군 구성요소의 수가 증가함에 따라 증가하며, 혈청 요산/크레아 티닌 비율은 대사증후군 및 그 구성요소와 관련이 있다고 보고 된다[11]. 이 연구결과는 혈청 요산/크레아티닌 비율의 상위 사 분위수에서 대사증후군 및 허리둘레 증가, 높은 혈압, HDL-C 감소의 발생빈도가 높았다. 또한 TG 증가는 혈청 요산/크레아 티닌 비율의 사분위수가 증가할수록 발생빈도가 증가하였다. 이는 혈청 요산/크레아티닌 비율과 대사증후군간에 관련이 있 으며, 혈청 요산/크레아티닌 비율의 상위 분위수에서 복부비만, 고중성지방혈증, 저 $\mathrm{HDL}-\mathrm{C}$ 및 고혈압 발병률이 증가한다는 연 구결과와 유사한 결과이다[11, 20]. 이 연구에서 흥미로운 점은 혈청 요산/크레아티닌 비율의 분위수가 증가할수록 공복혈당 과 $\mathrm{HbAlc}$ 가 감소하였다는 것이다. 이러한 결과는 Al-Daghri 등[11]의 연구에서도 나타나는데 혈청 요산/크레아티닌 비율 의 상위 삼분위수에서 공복혈당의 감소를 보여 혈청 요산/크레 아티닌 비율과 공복혈당간에 역상관 관계가 있음을 보고하였 다. 이는 혈당 증가가 과여과 상태(hyper filtration state)를 촉 진시켜 콩팥으로 요산 배설을 증가시키는 결과를 유발했기 때 문으로 설명되고 있으나[33], 정확한 기전을 설명하기 위해서 는 이를 뒷받침할 수 있는 후속 연구가 필요하겠다.

또한 $\mathrm{Gu}$ 등[19]은 제2형 당뇨병 환자에서 혈청 요산/크레아 티닌 비율은 만성 콩팥질환 발병과 연관되어 있으며, 만성 콩팥 질환 예측인자로서 혈청 요산보다 효율적인 지표라고 보고하였 다. 그러나 이러한 혈청 요산/크레아티닌 비율이 대사증후군 위 험을 예측하는데 사용될 수 있다는 증거는 매우 제한적이다[11, 20]. 이 연구에서는 연령과 BMI를 통제한 후 혈청 요산/크레아 티닌 비율은 대사증후군 발병과 관련이 없었으나, 요산은 1 사분 위수보다 4사분위수에서 대사증후군 발병 위험이 1.18 배 높게 나타났다. 또한 $\mathrm{ROC}$ 분석 결과 대사증후군 예측을 위한 혈청 요 산/크레아티닌 비율과 요산치의 AUC 값은 각각 $0.554,0.566$ 이었으며, 혈청 요산/크레아티닌 비율은 요산치보다 낮은 민감 도와 높은 특이도를 보였다. 따라서 선행연구에서 확인된 바와 같이 제2형 당뇨환자에서 혈청 요산/크레아티닌 비율은 대사증
후군과 밀접한 관련이 있지만, 이 연구에서는 건강한 성인 남성 을 대상으로 대사증후군 예측인자로서 혈청 요산/크레아티닌 비율의 효율성은 낮은 것으로 나타났다. 혈청 요산/크레아티닌 비율은 콩팥기능을 반영한 지수로서 이는 내인성 혈청 요산치 를 나타내며, 당뇨병 및 베타 세포 기능장애를 비롯한 대사장애 와 관련이 있다고 보고된다[34].

대사증후군의 정의는 개념상의 단점에 대한 몇 가지 논쟁이 있기는 하지만 심혈관 질환 위험이 높은 환자를 구별하는데 간 단하고 실용적인 도구로 널리 사용되고 있다[10]. 저자의 선행 연구를 보면 대사증후군을 예측하는 요산 AUC 값은 0.620 , 남 성은 0.564 로 나타났으며, 대사증후군을 예측하는 독립적인 지 표로서 한계가 있음을 제시하였다[35]. 이 연구결과는 대사증 후군 정의의 단점을 보완하는 지표로서 혈청 요산/크레아티닌 비율의 유용성을 확인한 결과 건강한 성인 남성의 대사증후군 위험을 예측하는 독립적인 지표로 사용하는데 제한이 있음을 시사하며, 보조적인 표지자로 사용하는 것이 바람직하겠다.

이 연구의 제한점은 횡단면 연구라는 특성 때문에 대사증후 군의 위험과 혈청 요산/크레아티닌 비율간의 인과관계를 추론 하는 것에 한계가 있다. 연령, BMI와 같은 일부 혼란 변수에 대 해 통제하였지만, 퓨린 섭취를 고려한 식습관, 운동과 같은 다른 요인에 대한 충분한 정보가 부족하여 이를 반영하지 못하였다. 또한 남성에서 고요산혈증 및 통풍의 발생빈도가 높다고 보고 되어 본 연구는 남성을 대상으로 연구를 진행하였으며[36], 이 결과는 여성에게 적용하는 데 제한이 있다.

결론적으로, 건강한 성인 남성을 대상으로 혈청 요산/크레아 티닌 비율은 1 사분위수보다 4 사분위수에서 대사증후군 및 대 사증후군 구성요소의 높은 발생빈도를 보였으나, 혈청 요산/크 레아티닌 비율이 대사증후군 위험 예측에 있어 혈청 요산치보 다 더 유용한 지표는 아닌 것으로 나타났다. 대사증후군 발병 기 전과 혈청 요산/크레아티닌간의 관계를 규명하기 위해 대상자 를 성별과 연령별로 구분하여 차이를 확인하는 연구가 필요하 겠다.

\section{요 약}

이 연구는 대사증후군 위험 예측인자로서 요산과 비교하여 혈청 요산/크레아티닌 비율의 유용성을 확인하고자 하였다. 2016년 11월부터 2018년 10월까지 수도권 소재의 일개 종합 병원에서 종합건강검진을 받은 20세 이상 80세 미만의 성인 남 성 14,190 명을 대상으로 하였다. 대사증후군 진단기준은 American Heart Association/National Heart Lung and 
Blood Institute (AHA/NHLBI)의 기준에 따라 5가지 대사증후 군 구성요소 중 3 가지 이상 해당되는 경우 대사증후군을 평가하 였으며, 이 중 복부비만은 WHO 서태평양지역의 기준에 따랐 다. 이 연구결과 혈청 요산/크레아티닌 비율은 1 사분위수보다 4 사분위수의 대사증후군 및 대사증후군 구성요소의 높은 발생빈 도를 보였다. 그러나 ROC 분석 결과 혈청 요산/크레아티닌 비 율은 대사증후군 위험 예측에 있어 혈청 요산치보다 더 유용한 지표는 아니었으며(AUC, 0.554 vs 0.566), 요산치보다 낮은 민 감도와 높은 특이도를 보였다. 결론적으로 혈청 요산/크레아티 닌 비율의 유용성을 확인한 결과 대사증후군 위험을 예측하는 독립적인 지표로 사용하는데 제한이 있으며, 보조적인 표지자 로 사용하는 것이 바람직하겠다.

\section{Acknowledgements: None \\ Conflict of interest: None \\ Author's information (Position): Kim MS ${ }^{1}$, M.T.; Shin $\mathrm{KA}^{2}$, Professor.}

\section{REFERENCES}

1. Alberti KG, Eckel RH, Grundy SM, Zimmet PZ, Cleeman JI, Donato KA, et al. Harmonizing the metabolic syndrome: a joint interim statement of the International Diabetes Federation Task Force on Epidemiology and Prevention; National Heart, Lung, and Blood Institute; American Heart Association; World Heart Federation; International Atherosclerosis Society; and International Association for the Study of Obesity. Circulation. 2009; 120:1640-1645. https://doi.org/10.1161/CIRCULATIONAHA.109. 192644.

2. Expert Panel on Detection, Evaluation, and Treatment of High Blood Cholesterol in Adults. Executive summary of the third report of the National Cholesterol Education Program (NCEP) expert panel on detection, evaluation, and treatment of high blood cholesterol in adults (Adult Treatment Panel III). JAMA. 2001;285:2486-2497.

3. Alberti KG, Zimmet P, Shaw J, IDF Epidemiology Task Force Consensus Group. The metabolic syndrome-a new worldwide definition. Lancet. 2005;366:1059-1062.

4. Alberti KG, Zimmet PZ. Definition, diagnosis and classification of diabetes mellitus and its complications. Part 1: diagnosis and classification of diabetes mellitus provisional report of a WHO consultation. Diabet Med. 1998;15:539-553. https://doi.org/ 10.1002/(SICI)1096-9136(199807)15:7〈539::AID-DIA668〉 3.0.CO;2-S,

5. Alberti KG, Zimmet P, Shaw J. Metabolic syndrome-a new world-wide definition. A Consensus Statement from the International Diabetes Federation. Diabet Med. 2006;23:469-480. https://doi.org/10.1111/j.1464-5491.2006.01858.x.

6. Shin KA. Association of metabolic syndrome with exercise capacity and heart rate recovery after treadmill exercise test. J
Exp Biomed Sci. 2011;17:305-311.

7. Shin KA. Association between resting heart rate and risk factors of metabolic syndrome in Korean men. The Journal of Korea Society for Wellness. 2015;10: 305-316.

8. Shin KA. Relationship between metabolic syndrome and pulmonary function in nonsmoker male. The Journal of the Korea Contents Association. 2014;14: 313-321. http://doi.org/10.5392/ JKCA.2014.14.12.313.

9. Shin KA. The relationship between metabolic syndrome risk factors and high sensitive C-reactive protein in abdominal obesity elderly women. Korean J Clin Lab Sci. 2017;49:121-127. https://doi.org/10.15324/kjcls.2017.49.2.121.

10. Thomas G, Sehgal AR, Kashyap SR, Srinivas TR, Kirwan JP, Navaneethan SD. Metabolic syndrome and kidney disease: a systematic review and meta-analysis. Clin J Am Soc Nephrol. 2011;6:2364-2373. https://doi.org/10.2215/CJN.02180311.

11. Al-Daghri NM, Al-Attas OS, Wani K, Sabico S, Alokail MS. Serum uric acid to creatinine ratio and risk of metabolic syndrome in Saudi type 2 diabetic patients. Sci Rep. 2017;7:12104. https://doi.org/10.1038/s41598-017-12085-0.

12. Dalton RN. Serum creatinine and glomerular filtration rate: perception and reality. Clin Chem. 2010;56:687-689. https:// doi.org/10.1373/clinchem.2010.144261.

13. Muntner P, He J, Hamm L, Loria C, Whelton PK. Renal insufficiency and subsequent death resulting from cardiovascular disease in the United States. J Am Soc Nephrol. 2002;13:745-753.

14. Chang IH, Han JH, Myung SC, Kwak KW, Kim TH, Park SW, et al. Association between metabolic syndrome and chronic kidney disease in the Korean population. Nephrology (Carlton). 2009;14:321-326. https://doi.org/10.1111/j.1440-1797.2009. 01091.x.

15. Johnson RJ, Feig DI, Herrera-Acosta J, Kang DH. Resurrection of uric acid as a causal risk factor in essential hypertension. Hypertension. 2005;45:18-20. https://doi.org/10.1161/01.HYP. 0000150785.39055.e8.

16. Nakagawa T, Hu H, Zharikov S, Tuttle KR, Short RA, Glushakova $\mathrm{O}$, et al. A causal role for uric acid in fructose-induced metabolic syndrome. Am J Physiol Renal Physiol. 2006;290:F625-F631. https://doi.org/10.1152/ajprenal.00140.2005.

17. Johnson RJ, Kang DH, Feig D, Kivlighn S, Kanellis J, Watanabe S, et al. Is there a pathogenetic role for uric acid in hypertension and cardiovascular and renal disease? Hypertension. 2003;41: 1183-1190. https://doi.org/10.1161/01.HYP.0000069700.62727. C5.

18. Quiñones Galvan A, Natali A, Baldi S, Frascerra S, Sanna G, Ciociaro D, et al. Effect of insulin on uric acid excretion in humans. Am J Physiol. 1995;268(1 Pt 1):E1-5. https://doi.org/ 10.1152/ajpendo.1995.268.1.E1.

19. Gu L, Huang L, Wu H, Lou Q, Bian R. Serum uric acid to creatinine ratio: A predictor of incident chronic kidney disease in type 2 diabetes mellitus patients with preserved kidney function. Diab Vasc Dis Res. 2017;14:221-225. https://doi.org/ 10.1177/1479164116680318.

20. Shin SR, Han AL. Relationship between metabolic syndrome and uric acid to creatinine ratio in Korean adults: Korea National Health and Nutrition Examination Survey 2016. Korean J Health Promot. 2018;18:113-118. https://doi.org/10. 
15384/kjhp.2018.18.3.113.

21. Grundy SM, Cleeman JI, Daniels SR, Donato KA, Eckel RH, Franklin BA, et al. Diagnosis and management of the metabolic syndrome: an American Heart Association/National Heart, Lung, and Blood Institute Scientific Statement. Circulation. 2005;112:2735-2752. https://doi.org/10.1161/CIRCULATIONAHA.105.169404.

22. World Health Organization regional office for the Western Pacific, International Diabetes Institute, International Association for the Study of Obesity, International Obesity Task Force. The Asia-Pacific perspective: redefining obesity and its treatment [Internet]. Sydney: Health Communications Australia; 2000 [cited 2019 February 16]. Available from: http://www. wpro.who.int/nutrition/documents/docs/Redefiningobesity.pdf.

23. Rathmann W, Funkhouser E, Dyer AR, Roseman JM. Relations of hyperuricemia with the various components of the insulin resistance syndrome in young black and white adults: the CARDIA study. Coronary Artery Risk Development in Young Adults. Ann Epidemiol. 1998;8:250-261.

24. Conen D, Wietlisbach V, Bovet P, Shamlaye C, Riesen W, Paccaud F, et al. Prevalence of hyperuricemia and relation of serum uric acid with cardiovascular risk factors in a developing country. BMC Public Health. 2004;4:9. https://doi.org/10.1186/ 1471-2458-4-9.

25. Kodama S, Saito K, Yachi Y, Asumi M, Sugawara A, Totsuka K, et al. Association between serum uric acid and development of type 2 diabetes. Diabetes Care. 2009;32:1737-1742. https:// doi.org/10.2337/dc09-0288.

26. Zhang L, Wang F, Wang X, Liu L, Wang H. The association between plasma uric acid and renal function decline in a Chinese population-based cohort. Nephrol Dial Transplant. 2012;27: 1836-1839. https://doi.org/10.1093/ndt/gfr597.

27. Zoppini G, Targher G, Chonchol M, Ortalda V, Abaterusso C, Pichiri I, et al. Serum uric acid levels and incident chronic kidney disease in patients with type 2 diabetes and preserved kidney function. Diabetes Care. 2012;35:99-104. https://doi. org/10.2337/dc11-1346.

28. Goicoechea M, de Vinuesa SG, Verdalles U, Ruiz-Caro C, Ampuero J, Rincón A, et al. Effect of allopurinol in chronic kidney disease progression and cardiovascular risk. Clin J Am Soc Nephrol. 2010;5:1388-1393. https://doi.org/10.2215/CJN.01580210.

29. Madero M, Sarnak MJ, Wang X, Greene T, Beck GJ, Kusek JW, et al. Uric acid and long-term outcomes in CKD. Am J Kidney Dis. 2009;53:796-803. https://doi.org/10.1053/j.ajkd.2008.12.021.

30. Sturm G, Kollerits B, Neyer U, Ritz E, Kronenberg F; MMKD Study Group. Uric acid as a risk factor for progression of non-diabetic chronic kidney disease? the Mild to Moderate Kidney Disease (MMKD) Study. Exp Gerontol. 2008;43:347352. https://doi.org/10.1016/j.exger.2008.01.006.

31. Jalal DI, Chonchol M, Chen W, Targher G. Uric acid as a target of therapy in CKD. Am J Kidney Dis. 2013;61:134-146. https:// doi.org/10.1053/j.ajkd.2012.07.021.

32. Jalal DI, Maahs DM, Hovind P, Nakagawa T. Uric acid as a mediator of diabetic nephropathy. Semin Nephrol. 2011;31:459-465. https://doi.org/10.1016/.semnephrol.2011.08.011.

33. Facchini F, Chen YD, Hollenbeck CB, Reaven GM. Relationship between resistance to insulin-mediated glucose uptake, urinary uric acid clearance, and plasma uric acid concentration. JAMA. 1991;266:3008-3011.

34. Li M, Gu L, Yang J, Lou Q. Serum uric acid to creatinine ratio correlates with $\beta$-cell function in type 2 diabetes. Diabetes Metab Res Rev. 2018;34:e3001. https://doi.org/10.1002/dmrr. 3001.

35. Shin KA. Clinical usefulness of serum uric acid and resting heart rate in the diagnosis of metabolic syndrome in Korean adults. Biomed Sci Letters. 2017;23:118-127. https://doi.org/10.15616/ BSL.2017.23.2.118.

36. Lee CH, Sung NY. The prevalence and features of Korean gout patients using the National Health Insurance Corporation Database. J Rheum Dis. 2011;18:94-100. https://doi.org/10. 4078/jrd.2011.18.2.94. 